\title{
Potassium fertilization of cauliflower and broccoli in a potassium-rich soil
}

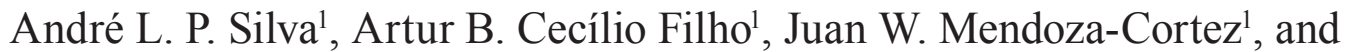 \\ Joaquim A. Lima Junior ${ }^{2}$ \\ ${ }^{1}$ Universidade Estadual Paulista, Via de acesso Prof. Paulo Donato Castellane, s/n, 14884-900, Jaboticabal, \\ São Paulo, Brazil. \\ ${ }^{2}$ Universidade Federal Rural da Amazônia, Av. Barão de Capanema, Bairro da Caixa d'água, s/n, 68700- \\ 700, Capanema, Pará, Brazil.
}

\begin{abstract}
A.L.P. Silva, A.B. Cecílio Filho, J.W. Mendoza-Cortez, and J.A. Lima Junior. 2016. Potassium fertilization of cauliflower and broccoli in a potassium-rich soil. Cien. Inv. Agr. 43(1):151-157. Cauliflower and broccoli are important vegetables but have lacking and divergent information about potassium $(\mathrm{K})$ fertilization in soil with a high $\mathrm{K}$ content. Two experiments were carried out from 2-1-2010 to 5-20-2010 in Jaboticabal City, São Paulo, Brazil, aiming to evaluate the effect of different $\mathrm{K}$ doses $\left(0,50,100,150\right.$ and $200 \mathrm{~kg} \mathrm{ha}^{-1} \mathrm{~K}_{2} \mathrm{O}$, in potassium chloride) on the yield of cauliflower 'Verona' and broccoli 'BRO 68' in Rhodic Eutrudox soil with a high $\mathrm{K}$ content. The broccoli and cauliflower responded positively but differently to potassium fertilization. The maximum yield of broccoli $\left(12,476 \mathrm{~kg} \mathrm{ha}^{-1}\right)$ was obtained with $160 \mathrm{~kg} \mathrm{ha}^{-1} \mathrm{~K}_{2} \mathrm{O}$, while the yield of cauliflower increased linearly with increasing $\mathrm{K}$ dose, yielding $38,285 \mathrm{~kg} \mathrm{ha}^{-1}$ with $200 \mathrm{~kg} \mathrm{ha}^{-1} \mathrm{~K}_{2} \mathrm{O}$.
\end{abstract}

Key words: Brassica oleracea var. botrytis, Brassica oleracea var. italica, productivity.

\section{Introduction}

Fertilizing agricultural soils is one of the most expensive agricultural practices, although its economic return is usually high due to its effects on productivity, product uniformity and quality (Ricci et al., 1995). In horticulture, because fertilization has a high economic return, farmers usually do not economize when applying fertilizers to the plants.

Received May 7, 2015. Accepted February 29, 2016. Corresponding author: rutra@fcav.unesp.br
Cauliflower and broccoli crops are among those with the highest demand for potassium; it is the second most absorbed nutrient by plants of these species (Castoldi et al., 2009; Takeishi et al., 2009). According to Islam et al. (2010), $\mathrm{K}$ is the most important nutrient for broccoli productivity. Increased plant resistance to diseases and drought stress, increased vegetable quality and increased efficiency of non-K nutrient use are the most important effects of K on plants (Armstrong, 1998).

Although the importance of potassium for cauliflower and broccoli productivity is well 
established, few studies have investigated the effects of this nutrient on the productivity of these species. Farmers frequently apply $\mathrm{K}$ fertilizers to horticultural plants in doses greater than those officially recommended because horticultural plants usually show positive responses to potassium fertilizers, even in potassium-rich soils. This procedure adopted by the farmers is probably based on the fertilizer dose recommendations found in tables for old cultivars that were less productive than are modern cultivars, which are highly responsive to soil fertilization.

Under soil conditions of high levels of available $\mathrm{K}$, the fertilizer recommendations for broccoli and cauliflower crops are divergent. Trani et al. (1997) recommend the application of $120 \mathrm{~kg} \mathrm{ha}^{-1}$ at the planting time of both species, followed by a dose of $60 \mathrm{~kg} \mathrm{ha}^{-1} \mathrm{~K}_{2} \mathrm{O}$ in a sidedress application. Fontes (1999a, b) recommended a dose of $20 \mathrm{~kg}$ $\mathrm{ha}^{-1}$ at planting and $80 \mathrm{~kg} \mathrm{ha}^{-1} \mathrm{~K}_{2} \mathrm{O}$ in a sidedress application. In potassium-rich soils, the Comissão de Química e Fertilidade do Solo (2004) recommended a dose of $220 \mathrm{~kg} \mathrm{ha}^{-1} \mathrm{~K}_{2} \mathrm{O}$. In addition to the discrepancies in the recommended doses, another intriguing fact is the recommendation of the same dose for two different horticultural species, given that this recommendation does not consider species differences regarding nutritional requirements, nutrient accumulation, productivity, spacing or other cultural practices.

Considering the abovementioned facts, the objective of this study was to verify the effects of different potassium fertilizer doses on the productivity of cauliflower and broccoli plants growing in a potassium-rich soil.

\section{Materials and methods}

\section{Experimental site}

Two experiments (cauliflower and broccoli) were carried out from February 01 to May 20, 2010, in the municipality of Jaboticabal, state of São
Paulo, Brazil, and at a latitude of $21^{\circ} 15^{\prime} 22^{\prime \prime} \mathrm{S}$, longitude of $48^{\circ} 18^{\prime} 58^{\prime}$ ' $\mathrm{W}$ and a mean altitude of $575 \mathrm{~m}$ above sea level.

\section{Soil type and characteristics}

The soil of the experimental area was classified as Rhodic Eutrudox (Soil Survey Staff, 1999). The textural and chemical analyses of the soil conducted with samples taken at depths between 0 and $20 \mathrm{~cm}$ before the experiment began produced the following results: 253,132 and $615 \mathrm{~g} \mathrm{~kg}^{-1}$ sand, silt and clay, respectively; $5.4 \mathrm{pH}\left(\mathrm{CaCl}_{2}\right) ; 20 \mathrm{~g}$ $\mathrm{kg}^{-1}$ organic matter; $103 \mathrm{mg} \mathrm{dm}{ }^{-3} \mathrm{P}$ (resin); 3.6, 25, 7, 28 and $64 \mathrm{mmol}_{\mathrm{c}} \mathrm{dm}^{-3} \mathrm{~K}, \mathrm{Ca}, \mathrm{Mg}, \mathrm{H}+\mathrm{Al}$, and cation exchange capacity, respectively; and $56 \%$ soil base saturation.

\section{Treatments, experimental design and experimental unit}

Doses of $0,50,100,150$, and $200 \mathrm{~kg} \mathrm{ha}^{-1} \mathrm{~K}_{2} \mathrm{O}$ were evaluated; these doses were adopted considering the report of Trani et al. (1997), who recommended $120 \mathrm{~kg} \mathrm{ha}^{-1} \mathrm{~K}_{2} \mathrm{O}$ for cauliflower and broccoli when the $\mathrm{K}$ content in the soil is high. In each experiment, the experimental units were distributed in the field according to a randomized complete block design with four replications. The experimental unit was composed of two six-plant rows, of which only the four central plants were used for experimental data.

\section{Plant material, planting and harvesting}

The seedlings of cauliflower 'Verona' and broccoli 'BRO 68' cultivars were grown in propylene trays with space enough for 200 seedlings in a BIOPLANT organic mineral substratum (Bioplant Agrícola Ltda, Nova Ponte city, Minas Gerais, Brazil). Transplantation to the seed bed took place on February 1, 2010, when the seedlings exhibited four leaves. Cauliflower seedlings were 
placed at a distance of $0.7 \mathrm{~m}$ between rows and $0.50 \mathrm{~m}$ between plants. Broccoli seedlings were placed at a distance of $0.7 \mathrm{~m}$ between rows and $0.35 \mathrm{~m}$ between plants in the row. The distance between seed beds was $0.5 \mathrm{~m}$. Cauliflower was harvested from May 14 to 20, and broccoli was harvested from April 2 to 13, 2010.

\section{Management practices}

Soil liming of the whole area was performed to increase the soil base saturation to $80 \%$ using calcined lime with a neutralization power of $124 \%$ and $\mathrm{CaO}$ and $\mathrm{MgO}$ contents of $48 \%$ and $16 \%$, respectively. The mineral fertilization of the seed beds took place immediately before the seedling transplantation, and the amounts of fertilizers that were used were based on the recommendations of Trani et al. (1997). The $\mathrm{N}$, P, and $\mathrm{K}$ sources were, respectively, urea, superphosphate, and potassium chloride. No organic fertilizer was applied. The sidedressing of fertilizers also followed the recommendations of Trani et al. (1997), although the doses were applied only at 15,30 , and 45 days after transplantation (DAT). Approximately $40 \%$ of the total $\mathrm{K}$ of each treatment was applied at planting, and the remaining portion was divided and applied at the aforementioned moments. Irrigation was provided throughout the plant life cycle using a sprinkler system.

\section{Parameters that were evaluated}

The potassium foliar content was measured in the leaf that developed immediately after the inflorescence started to grow, according to the instructions of Trani and Raij (1997). The potassium soil content was determined after harvest, according to methodology proposed by Raij et al. (2001). The mass and diameter of the inflorescence and the productivity were also determined.

\section{Data analysis}

An analysis of variance and a polynomial regression of the data were performed. The equation with a significant $\mathrm{F}$ and with the highest determination coefficient was chosen.

\section{Results and discussion}

\section{Foliar K content}

The potassium level in cauliflower leaves was influenced by $\mathrm{K}$ doses. A quadratic adjustment was found for $\mathrm{K}$ levels in the leaves and $\mathrm{K}$ doses. The $\mathrm{K}$ levels in the leaves increased from 29.2 $\mathrm{g} \mathrm{kg}^{-1}$ when the $\mathrm{K}_{2} \mathrm{O}$ dose was null to $34.9 \mathrm{~g} \mathrm{~kg}^{-1}$ when the $\mathrm{K}_{2} \mathrm{O}$ dose was $200 \mathrm{~kg} \mathrm{ha}^{-1}$. In broccoli plants, however, the $\mathrm{K}$ foliar level was not influenced by $\mathrm{K}_{2} \mathrm{O}$ dose - the mean value was $34.4 \mathrm{~g}$ $\mathrm{kg}^{-1}$ (Figure 1).

The potassium foliar levels found for both cauliflower and broccoli plants were within the adequate ranges ( 25 to $50 \mathrm{~g} \mathrm{~kg}^{-1}$ ) according to Trani and Raij (1997). The difference in the response shown by cauliflower and broccoli should be due the better adaptation displayed by the cauliflower cultivar to the high temperatures that were registered during the experiment. Although both cultivars are recommended for summer cultivation, broccoli cultivars have shown poor growth and productivity

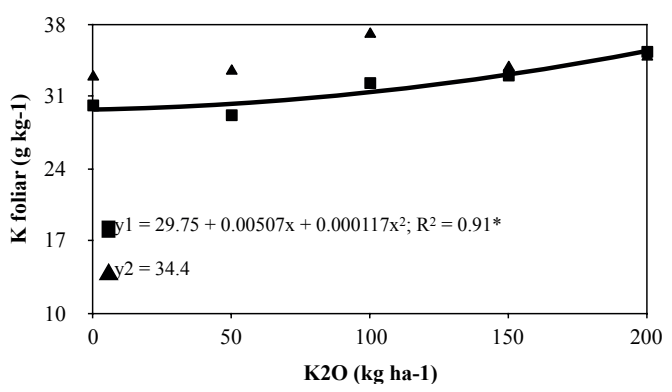

Figure 1. Potassium foliar level in cauliflower 'Verona' (y1) and broccoli 'BRO 68' (y2) as a function of the $\mathrm{K}_{2} \mathrm{O}$ doses. 
when the environmental conditions include high temperatures and pluvial precipitation, indicating that genetic improvement for more heat-tolerant broccoli cultivars is needed. This explains - at least partially - why increased doses of $\mathrm{K}_{2} \mathrm{O}$ did not result in increased levels of potassium in broccoli leaves. Highly productive cauliflower cultivars for summer, winter, and midseason conditions are available.

\section{Inflorescence diameter}

The effects of $\mathrm{K}_{2} \mathrm{O}$ doses on the inflorescence diameter were different for cauliflower and broccoli. In cauliflower, the response of the inflorescence diameter to $\mathrm{K}_{2} \mathrm{O}$ doses showed a polynomial quadratic adjustment pattern starting from $50 \mathrm{~kg}$ $\mathrm{ha}^{-1}$ (the maximum diameter of $21.8 \mathrm{~cm}$ resulted from the $\mathrm{K}_{2} \mathrm{O}$ dose of $200 \mathrm{~kg} \mathrm{ha}^{-1}$ ). In broccoli plants, the inflorescence diameter increased with $\mathrm{K}_{2} \mathrm{O}$ doses up to $150 \mathrm{~kg} \mathrm{ha}^{-1}$, which was the dose that resulted in the highest diameter: $14.6 \mathrm{~cm}$ (Figure 2a).

Increments in the inflorescence diameter were less expressive in broccoli than in cauliflower. Monteiro et al. (2010) observed a diameter of $25.3 \mathrm{~cm}$ in cauliflower plants of the 'Verona' cultivar growing under summer conditions in Jaboticabal.

\section{Inflorescence mass}

The inflorescence mass increased with $\mathrm{K}_{2} \mathrm{O}$ doses. The highest inflorescence masses in cauliflower $(1,086.3 \mathrm{~g})$ and in broccoli (362.1 g) resulted from the respective $\mathrm{K}_{2} \mathrm{O}$ doses of 200 and $155 \mathrm{~kg} \mathrm{ha}^{-1}$ (Figure $2 b$ ). The mass in this experiment was similar to that $(1,120 \mathrm{~g})$ reported by Monteiro et al. (2010) in work with the 'Verona' cultivar in a summer experiment for the observation of cauliflower hybrids. This value was, however, larger than that reported by Pôrto et al. (2012) (860 g) in an experiment in which the plants grew at the same population density. Islam et al. (2010) also reported responses with quadratic adjustments of the broccoli inflorescence diameter and mass to $\mathrm{K}_{2} \mathrm{O}$ doses - these authors used doses ranging from 0 to $360 \mathrm{~kg} \mathrm{ha}^{-1} \mathrm{~K}_{2} \mathrm{O}$.

These authors also verified that the maximal inflorescence diameter and mass were gained when the $\mathrm{K}_{2} \mathrm{O}$ dose was of $240 \mathrm{~kg} \mathrm{ha}^{-1}$ and that doses larger than this started to have depressing effects on those characteristics. The productivity of both cauliflower and broccoli plants was significantly influenced by $\mathrm{K}_{2} \mathrm{O}$ doses.

\section{Productivity}

Cauliflower productivity was observed to increase linearly with doses of $\mathrm{K}_{2} \mathrm{O}$ - the dose of $200 \mathrm{~kg}$ $\mathrm{ha}^{-1}$ resulted in a yield of $38,285 \mathrm{~kg} \mathrm{ha}^{-1}$ (Figure 3). This dose is larger than that recommended by Fontes $(1999 \mathrm{a}, \mathrm{b})\left(100 \mathrm{~kg} \mathrm{ha}^{-1}\right)$ and is close to that recommended by Trani et al. (1997) $(180 \mathrm{~kg}$ $\mathrm{ha}^{-1}$ ) for potassium-rich soils. When $\mathrm{K}$ fertilizer
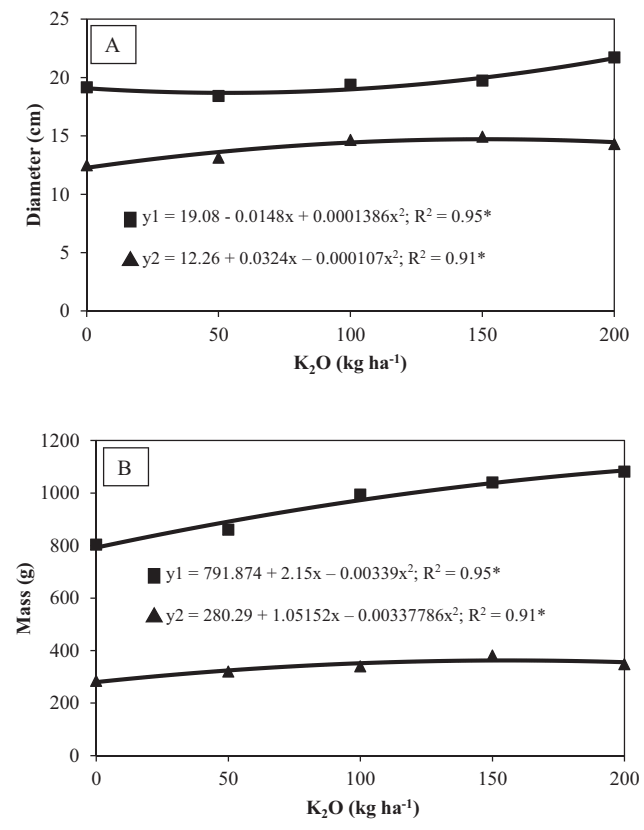

Figure 2. Diameter (A) and mass (B) of cauliflower 'Verona' (y1) and broccoli 'BRO 68' (y2) as a function of the $\mathrm{K}_{2} \mathrm{O}$ doses. 
was not applied, the inflorescence production was $30,351 \mathrm{~kg} \mathrm{ha}^{-1}$, a value representing $79 \%$ of the maximum yield (Figure 3 ). A high productivity without the application of $\mathrm{K}$ may be ascribed to high soil fertility with a high level of $\mathrm{K}-3.6$ $\mathrm{mmol}_{\mathrm{c}} \mathrm{dm}^{-3}$. However, when $\mathrm{K}_{2} \mathrm{O}$ fertilizer was applied to the soil, cauliflower was responsive, and an increase of $40 \mathrm{~kg} \mathrm{ha}^{-1}$ in inflorescence was registered for each $1 \mathrm{~kg}$ of $\mathrm{K}_{2} \mathrm{O}$ fertilizer that was applied.

The maximum productivity verified for cauliflower is approximately twice as much as the national average $\left(20,000 \mathrm{~kg} \mathrm{ha}^{-1}\right)$. In an experiment in which cauliflower genotypes were evaluated during the summer, Monteiro et al. (2010) found a productivity of $22,340 \mathrm{~kg} \mathrm{ha}^{-1}$ for the 'Verona' cultivar and a productivity between 14,560 and $23,760 \mathrm{~kg} \mathrm{ha}^{-1}$ for the other hybrids. Pôrto et al. (2012) reported productivities between 11,381 and $23,035 \mathrm{~kg} \mathrm{ha}^{-1}$ for the 'Verona' cultivar, depending on the plant population.

Broccoli productivity showed an adjustment to the quadratic equation in response to $\mathrm{K}_{2} \mathrm{O}$ doses, with a maximum yield of $12,476 \mathrm{~kg} \mathrm{ha}^{-1}$ when the $\mathrm{K}_{2} \mathrm{O}$ dose was $160 \mathrm{~kg} \mathrm{ha}^{-1}$ (Figure 3). This dose is slightly greater than that recommended by Fontes (1999a, b) and close to that recommended by Trani et al. (1997) (180 kg ha-1 $\mathrm{K}_{2} \mathrm{O}$ when the lowest side-dressed dose - 60 $\mathrm{kg} \mathrm{ha}^{-1}$ - is added to the $120 \mathrm{~kg} \mathrm{ha}^{-1}$ applied at planting). The productivity, however, is lower than that reported by Cecílio Filho et al. (2012), who evaluated the distance between plants and the doses of $\mathrm{N}$ and $\mathrm{K}$ and verified a 'Mônaco' broccoli productivity of 22,082 $\mathrm{kg} \mathrm{ha}^{-1}$ in the best treatment ( $315 \mathrm{~kg} \mathrm{ha}^{-1} \mathrm{~N}$ and $\mathrm{K}_{2} \mathrm{O}$ and a spacing combination of $0.2 \mathrm{~m}$ between plants and $0.8 \mathrm{~m}$ between rows). However, this experiment used an Autumn crop, which was more favorable for productivity, and had a larger plant population because the authors did not cultivate broccoli in seed beds. Islam et al. (2010) verified larger yields with $240 \mathrm{~kg} \mathrm{ha}^{-1} \mathrm{~K}_{2} \mathrm{O}$ when evaluating doses from 0 to $360 \mathrm{~kg} \mathrm{ha}^{-1} \mathrm{~K}_{2} \mathrm{O}$.

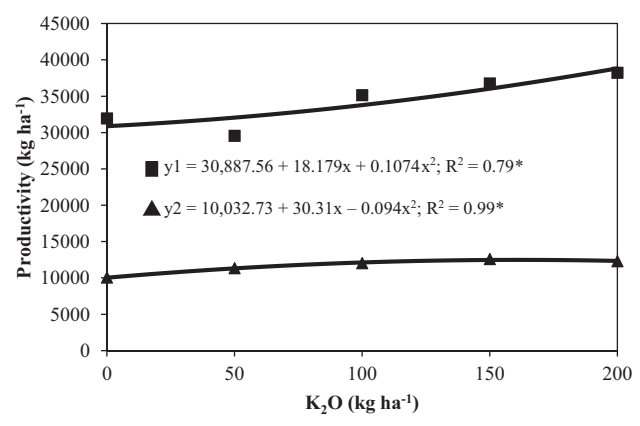

Figure 3. Cauliflower 'Verona' (y1) and broccoli 'BRO 68' (y2) productivity as a function of the $\mathrm{K}_{2} \mathrm{O}$ doses.

Examining the productivity of both species, it was verified that broccoli was agronomically more efficient than cauliflower because up to a dose of $70 \mathrm{~kg} \mathrm{ha}^{-1}$, broccoli produced a higher inflorescence per kilogram of $\mathrm{K}_{2} \mathrm{O}$. Doses higher than this $\left(100,150\right.$, and $\left.200 \mathrm{~kg} \mathrm{ha}^{-1}\right)$ decreased the broccoli agronomical efficiency, with respective yields of 20.9, 16.2, and $11.5 \mathrm{~kg}$ of inflorescence per kilogram of $\mathrm{K}_{2} \mathrm{O}$. These same $\mathrm{K}_{2} \mathrm{O}$ doses resulted in 28.9, 34.3, and $39.7 \mathrm{~kg}$ of cauliflower inflorescence per kilogram of $\mathrm{K}_{2} \mathrm{O}$. When cauliflower and broccoli were applied respective maximizing doses of 200 and $160 \mathrm{~kg} \mathrm{ha}^{-1} \mathrm{~K}_{2} \mathrm{O}$, the agronomical efficiencies were, respectively, 39.7 and $15.1 \mathrm{~kg}$ of inflorescence per kilogram of $\mathrm{K}_{2} \mathrm{O}$.

The level of potassium in the soil was significantly influenced by $\mathrm{K}_{2} \mathrm{O}$ dose. When no $\mathrm{K}$ was applied, the $\mathrm{K}$ levels in the soil were 1.8 and $2.5 \mathrm{mmol}_{\mathrm{c}} \mathrm{dm}^{-3}$ in the cauliflower and broccoli areas, respectively. With increasing $\mathrm{K}_{2} \mathrm{O}$ doses of up to $200 \mathrm{~kg} \mathrm{ha}^{-1}$, the $\mathrm{K}$ level in the soil increased linearly, reaching 4.0 and $4.5 \mathrm{mmol}_{\mathrm{c}} \mathrm{dm}^{-3}$ in the cauliflower and broccoli areas, respectively (Figure 4).

The level of $\mathrm{K}$ in the soil before the experiment began, $3.6 \mathrm{mmol}_{\mathrm{c}} \mathrm{dm}^{-3}$, was maintained after the inflorescences were harvested when cauliflower and broccoli were fertilized with 165 and $110 \mathrm{~kg}$ ha $^{-1} \mathrm{~K}_{2} \mathrm{O}$, respectively (Figure 4). Doses higher than these resulted in increased levels of $\mathrm{K}$ in the soil with increments compared to the initial level 
of $11 \%$ and $25 \%$, with the initial level already being a high value, according to Raij et al. (1997). The lower recovery of the applied nutrient shown by broccoli plants compared to that shown by cauliflower indicates differences between the two species, probably influenced by the adaptability to the cropping environment. Pôrto et al. (2012), when evaluating the effects of the time of 'Verona' cauliflower cultivation (Spring-Summer and Autumn-Winter), reported significant differences in the number of leaves, stem diameter, inflorescence diameter, inflorescence mass, productivity, and cycle.

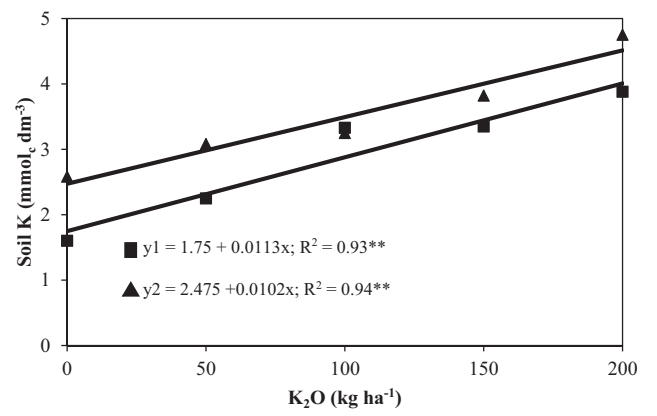

Figure 4. Potassium level in the soil as a function of the $\mathrm{K}_{2} \mathrm{O}$ doses in areas of cauliflower 'Verona' (y1) and broccoli 'BRO 68' (y2).
When cauliflower and broccoli were cultivated with $\mathrm{K}_{2} \mathrm{O}$ doses lower than 165 and $110 \mathrm{~kg}$ ha $^{-1} \mathrm{~K}_{2} \mathrm{O}$, respectively, the $\mathrm{K}$ levels in the soil decreased. These reductions increased as the $\mathrm{K}_{2} \mathrm{O}$ doses decreased and reached $50 \%$ and $30 \%$ for cauliflower and broccoli, respectively, cultivated without potassium fertilizer. The greater reduction in $\mathrm{K}$ level in the soil for cauliflower plants may be attributed to the greater $\mathrm{K}$ demand shown by this species than by broccoli, as reported by Castoldi et al. (2009) and Takeishi et al. (2009). The results for cauliflower inflorescence diameter and mass and yield suggest that this brassica was not negatively affected by the increased $\mathrm{K}$ level in the soil, which reached $4.5 \mathrm{mmol}_{\mathrm{c}} \mathrm{dm}^{-3}$ when the highest dose of $\mathrm{K}_{2} \mathrm{O}$ was applied (Figure 4), different from that observed for broccoli.

Based on the observed results, broccoli and cauliflower plants growing in K-rich soils respond to $\mathrm{K}$ fertilization. The maximum yield of broccoli was reached when the $\mathrm{K}_{2} \mathrm{O}$ dose was $160 \mathrm{~kg}$ ha 1 , and that of cauliflower was reached when this dose was $200 \mathrm{~kg} \mathrm{ha}^{-1}$.

\section{Resumen}

A.L.P. Silva, A.B. Cecílio Filho, J.W. Mendoza-Cortez, y J.A. Lima Junior. 2016. Fertilización potásica de coliflor y brócoli en un suelo con alta concentración de potasio. Cien. Inv. Agr. 43(1):151-157. La coliflor y el brócoli son dos hortalizas económicamente importantes, sin embargo carecen de informaciones acerca de la fertilización con potasio (K) en suelo con alta concentración de ese nutriente. En ese contexto, fueron realizados dos experimentos del 01 de febrero al 20 de mayo de 2010, en la ciudad de Jaboticabal, São Paulo, Brazil, con el objetivo de evaluar cinco dosis de $\mathrm{K}\left(0,50,100,150\right.$ y $\left.200 \mathrm{~kg} \mathrm{ha}^{-1} \mathrm{de} \mathrm{K}_{2} \mathrm{O}\right)$, utilizando cloruro de potasio, sobre la productividad de la coliflor 'Verona' y del brócoli 'BRO68', en suelo tipo Rhodic Eutrudox con alta concentración de K. El brócoli y la coliflor respondieron positivamente a la fertilización con potasio, pero con respuestas diferenciadas. La máxima productividad del brócoli (12 $\left.476 \mathrm{~kg} \mathrm{ha}^{-1}\right)$ se obtuvo con $160 \mathrm{~kg} \mathrm{ha}^{-1}$ de $\mathrm{K}_{2} \mathrm{O}$, mientras que la productividad de la coliflor aumentó linealmente con el incremento de las dosis de $\mathrm{K}$, produciendo $38285 \mathrm{~kg} \mathrm{ha}^{-1}$ con $200 \mathrm{~kg} \mathrm{ha}^{-1}$ de $_{2} \mathrm{O}$.

Palabras clave: Brassica oleracea var. botrytis, Brassica oleracea var. italica, productividad. 


\section{References}

Armstrong, D.L. 1998. Potassium for agriculture. Better Crops with Plant Food 82:4-5.

Castoldi, R., H.C.O. Charlo, P.F. Vargas, and L.T. Braz. 2009. Crescimento, acúmulo de nutrientes e produtividade da cultura da couve-flor. Horticultura Brasileira 27:438-446.

Cecílio Filho, A.B., A.A. Schiavon Júnior, and J.W.M. Cortez. 2012. Produtividade e classificação de brócolis para indústria em função da adubação nitrogenada e potássica e dos espaçamentos entre plantas. Horticultura Brasileira 30:12-17.

Comissão de Química e Fertilidade do Solo - RS/SC. 2004. Manual de adubação e de calagem para os Estados do Rio Grande do Sul e de Santa Catarina. 10 ed. Sociedade Brasileira de Ciência do Solo, Porto Alegre. Rio Grande do Sul, Brasil. 400 pp.

Fontes, P.C.R. 1999a. Brócolos. p. 183. In: Ribeiro, A.C., P.T.G. Guimarães, e V.H Alvarez V. (eds.). Recomendação para uso de corretivos e fertilizantes em Minas Gerais. Comissão de Fertilidade do Solo do Estado de Minas Gerais, Viçosa, Minas Gerais, Brasil.

Fontes, P.C.R. 1999b. Couve-Flor. p. 187. In: Ribeiro, A.C., P.T.G. Guimarães, e V.H. Alvarez V. (eds.). Recomendação para uso de corretivos e fertilizantes em Minas Gerais. Comissão de Fertilidade do Solo do Estado de Minas Gerais, Viçosa, Minas Geras, Brasil. $5^{\mathrm{a}}$ aproximação.

Islam, M.H., M.R. Shaheb, S. Rahman, B. Ahmed, A.T.M.T. Islam, and P.C. Sarker. 2010. Curd yield and profitability of broccoli as affected by phosphorus and potassium. International Journal of Sustainable Crop Production 5:1-7.

Monteiro, B.C.B.A., H.C.O. Charlo, and L.T. Braz. 2010. Desempenho de híbridos de couve-flor de verão em Jaboticabal. Horticultura Brasileira 28:115-119.

Pôrto, D.R.Q., A.B. Cecílio Filho, B.L.A. Rezende, A.P. Barros Júnior, and G.S. Silva. 2012. Densi- dade populacional e época de plantio no crescimento e produtividade da couve-flor cv. Verona 284. Revista Caatinga 25:92-98.

Raij, B. van, J.C. Andrade, H. Cantarella, and J.A. Quaggio. 2001. Análise química para avaliação da fertilidade de solos tropicais. Instituto Agronômico \& Fundação IAC, Campinas, São Paulo, Brasil. 285 pp.

Raij, B. van, H. Cantarella, J.A. Quaggio, and A.M.C. Furlani. 1997. Fósforo e potássio. p. 9-10. In: Raij, B. van, H. Cantarella, J.A. Quaggio, and A.M.C. Furlani (eds.). Recomendações de adubação e calagem para o Estado de São Paulo. 2 ed. Instituto Agronômico \& Fundação IAC, Campinas, São Paulo, Brasil.

Ricci, M.S.F., V.W.D. Casali, A.A. Cardoso, and H.A. Ruiz. 1995. Teores de nutrientes em duas cultivares de alface adubadas com composto orgânico. Pesquisa Agropecuária Brasileira 30:1035-1039.

Soil Survey Staff. 1999. Soil taxonomy: A basic system of soil classification for making and interpreting soil surveys. Natural Resources Conservation Service, Department of Agriculture, Washington DC, United States. 754 pp.

Takeishi, J., A.B. Cecílio Filho, and P.R. Oliveira. 2009. Crescimento e acúmulo de nutrientes em couve-flor 'Verona'. Bioscience Journal 25:110.

Trani, P.E., F.A. Passos, J.A. Azevedo, and M. Tavares. 1997. Brócolos, couve-flor e repolho. p. 175. In: Raij, B. van, H. Cantarella, J.A. Quaggio, and A.M.C. Furlani (eds.). Recomendações de adubação e calagem para o Estado de São Paulo. 2 ed. Instituto Agronômico \& Fundação IAC, Campinas, São Paulo, Brasil.

Trani, P.E., and B. van Raij. 1997. Hortaliças. p. 157185. In: Raij, B. van, H. Cantarella, J.A. Quaggio, and A.M.C. Furlani (eds.). Recomendações de adubação e calagem para o Estado de São Paulo. 2 ed. Instituto Agronômico \& Fundação IAC, Campinas, São Paulo, Brasil. 
